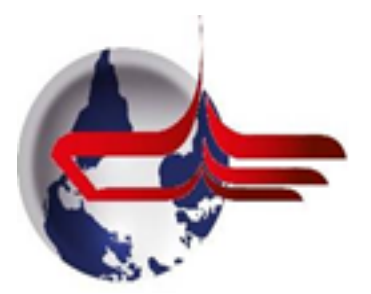

Turkish Journal of Educational Studies, 5 (3) Ekim 2018 Research Article / Araştırma Makalesi

Article Info/Makale Bilgisi

Received/Geliş: Ağustos 2018 Accepted/Kabul: Ekim 2018

\title{
Ortaokul Öğretmenlerinin Özyeterlik Düzeyleri: Elazı̆̆ İli Örneği
}

\section{Secondary School Teachers' Self-Efficacy Levels: Elazig Province Sample}

\author{
Necmi GÖKYER* Serkan BAKCAK**
}

\section{$\ddot{O} z$}

$\mathrm{Bu}$ araştırmanın amacı, ortaokul öğretmenlerinin özyeterlik düzeylerini belirlemektir. Bu araştırma anlık tarama modelindedir. Araştırmanın evrenini, Araştırmanın evrenini, 2017-2018 eğitim öğretim yılında, Elazığ merkez ve ilçelerin merkezindeki ortaokullarda görev yapan toplam 1602; Örneklemini ise, basit tesadüfi örnekleme yolu ile belirlenen toplam 360 öğretmen oluşturmaktadır. Araştırmada veri toplama aracı olarak, Orijinali Tschannen-Moran ve Hoy (2001) tarafindan geliştirilen ve Çapa, Çakıroğlu, Sarıkaya (2005) tarafindan Türkçe'ye uyarlanan Öğretmen Öz-Yeterlik Ölçeği kullanılmıştır. Araştırmaya katılan branş öğretmenlerinin bütün alt boyutlarda ve ölçeğin tamamında mesleki öz yeterlik düzeyleri oldukça yeterlidir. Cinsiyet değişkenine göre, sınıf yönetimine yönelik özyeterlik, öğretim stratejilerine yönelik özyeterlik alt boyutlarında ve ölçeğin tamamında erkek öğretmenlerin özyeterlik düzeyleri kadın öğretmenlere göre daha yüksektir. Öğrenci sayısı az olan okullarda görev yapan öğretmenlerin özyeterlik düzeylerinin, öğrenci sayısı yüksek olan okullarda görev yapanlara göre daha düşük olduğu saptanmıştır. Kıdem, branş, çalıştıları yerleşim yeri, okuldaki görev süresi ve eğitim düzeyi değişkenlerine göre, branş öğretmenlerinin özyeterlik düzeyleri arasında anlamlı bir fark çıkmamıştır.

Anahtar sözcükler: Branş öğretmeni, özyeterlik, ortaokul

\begin{abstract}
The purpose of this research is to determine the self-efficacy levels of secondary school teachers. This research is in the instant scanning model. The universe of the research constitutes a total of 1602 teachers working in middle schools in the center of Elazığ and the districts in the academic year of 2017-2018. The sample forms a total of 360 teachers determined by simple random sampling. "Teachers' Sense of Efficacy Scale" developed by Tschannen-Moran and Hoy (2001) and adapted to Turkish by Çapa, Çakıroğlu and Sarıkaya (2005) was used as the data collection tool in the research. Professional self-efficacy levels of the branch teachers participating in the research are sufficient in all sub-dimensions and in the whole scale.
\end{abstract}

*Doç. Dr. Fırat Üniversitesi, Eğitim Fakültesi Eğitim Bilimleri Bölümü, El-mek: ngokyer@firat.edu.tr

**Fırat Üniversitesi, Eğitim Fakültesi Eğitim Bilimleri Bölümü Doktora öğrencisi, El-mek: sbakcak@bingöl.edu.tr 
According to the gender variable, the sub-dimensions of self-efficacy for classroom management and selfefficacy for teaching strategies and in the whole scale, self-efficacy levels of male teachers are higher than female teachers. It was determined that self-efficacy levels of teachers who work in schools with a small number of students are lower than those who work in schools with a high number of students. There is no significant difference between the self-efficacy levels of the branch teachers according to the variables such as seniority, branch, place of work, duration at the school and education level.

Keywords: Branch teacher, middle school, self-efficacy

\section{GİRIS}

Eğitim sistemlerinin nihai amac1; topluma faydalı, toplumsal değerleri gözeten, etkili iletişim becerilerini edinmiş, değişime uyum sağlayabilen, öğrenme kaynaklarına erişme ve bunlardan etkin bir şekilde yararlanma becerilerini kazanmış, iletişim teknolojilerini verimli kullanabilen, kendisiyle ve toplumla barışık, inisiyatif alan, araştıran, sorgulayan ve eleştirel düşünme becerilerine sahip özgür bireyler yetiştirebilmektir. Bu niteliklere sahip bireylerden oluşacak bir toplumun inşasında en önemli görev ise öğretmenlere düşmektedir.

Öğretmenlik mesleği yalnızca alan bilgisinin kullanıldığı ve teorik sınırlar içinde sürdürülen bir meslek değildir. Öğretmenlerin belli değerlere sahip olma yanında öğretecekleri alana dair pedagojik alan yeterlikleri ile iletişim ve sınıf yönetimi gibi genel pedagojik yeterliklere de sahip olması gerekir. Öğretmenlik mesleğinin gerektirdiği bu çok yönlü yeterlikleri kazanabilmek için şüphesiz yüksek nitelikte bir eğitim sürecinden geçmek gerekmektedir (Öğretmen Strateji Belgesi, 2017-2023). Ulusal ve uluslararası düzeydeki düzenlemeler ve eğitim alanındaki yeni gelişmeler ile birlikte eğitim sistemimizdeki yeniliklere uyum sağlayabilmek için öğretmenlik mesleği genel yeterlikleri güncellenmiş her bir öğretmenlik alanı için ayrı bir özel alan yeterliği belirlemek yerine bütünsel mahiyette öğretmenlik mesleği genel yeterlikleri belirlenmiştir. Bu yeterlikler mesleki bilgi, mesleki beceri ve tutum ve değerlerdir. Bunlara bağlı olarak 11 alt yeterlik ve 65 gösterge belirlenmiştir (Öğretmen Yetiştirme ve Geliştirme Genel Müdürlüğ̈̈, 2017, s. 8).

Öğretmenlerin öğretmenlik mesleğinin gerektirdiği bilgi ve becerilere sahip olmalarının yanı sıra, öğretmen niteliğini etkileyen bir diğer faktör de onların görev ve sorumluluklarını yerine getirebileceklerine olan inançlarıdır (Çapa Aydın, Uzuntiryaki Kundakçı, Temli ve Tarkın, 2013). Bandura (1997) başarılı olabilmek için gerekli yeteneklere sahip olmanın yanı sıra, bireyin başaracağına olan inancının da önemli olduğunu vurgulamıştır. Başka bir deyişle, başarılı olmada özyeterlik inancı da etkilidir. Öğretmenler alan bilgileri bakımından yeterli olsalar dahi, öğretmenlik mesleğine yönelik öz yeterlik duygusundan yoksun olmaları halinde öğrenme ve öğretme süreçlerinde verimli olmaları beklenemez (Şahin, 2010, s. 27). Eğitimde kalitenin yakalanabilmesi için öğretim programları, öğretim materyalleri, fiziksel donanım, teknolojik alt yapı gibi dikkat edilecek öğeler de vardır. Ancak eğitim ve öğretimin girdileri olarak değerlendirilen bu öğelerin öğrenmeye katkıs1 doğrudan öğretmenlerin yeterliklerine bağlıdır. Çünkü çeşitli fiziksel donanımları, eğitim teknolojileri 
ve eğitim materyallerini kullanarak öğretim programlarını hayata geçirecek olan öğretmenlerdir (Ayra ve Kösterelioğlu, 2015). Bu kaynakları etkin bir şekilde kullanarak öğrencilerin bilişsel, duyuşsal ve sosyal gelişimlerini sağlamak, mesleki açıdan yeterlik kazanmış öğretmenlerle mümkündür (Zayimoğlu Öztürk, 2011, s. 46). Öğretmen öz yeterliği denilince öğretmenin sınıf yönetimindeki yeterlikleri, öğrencileriyle ilişkileriyle ilgili yeterlikleri ve öğretim stratejilerini kullanmadaki yeterliğe olan inancı akla gelmektedir. Öz-yeterlik inancı kavramını ilk ortaya atan Bandura'dır (Santrock 2000).

Öz-yeterlik inanc1, Bandura (1986, s. 391) tarafından "kişilerin bir performans1 gerçekleştirebilmek için gerekli olan eylemleri yerine getirebilme ve bu eylemleri organize edebilme kapasiteleri hakkındaki yargıları" olarak tanımlanmıştır (Akbaş ve Çelikkaleli, 2006). Ayrıca bu inancının insan yaşamında önemli bir yere sahip olan (a) bilişsel süreçleri, (b) motivasyonel süreçleri, (c) duygusal süreçleri ve (d) seçim yapma süreçleri gibi dört temel psikolojik süreci de etkilediği belirtilmektedir (Bandura, 1997, s. 5). Zimmerman (1995) ise, öz-yeterlik kavramını bireyin bir işi gerçekleştirebilme, başarabilme yeteneği konusundaki kişisel yargısı olarak tanımlamaktadır. Öğretmen öz-yeterliği, öğretmenin belirli bir bağlamda öğretmenlik görevini başarması için gerekli olan eylemi gerçekleştirmeye ve organize etmeye yönelik kapasitesi ile ilgili inançlarıdır (TschannenMoran, Hoy ve Hoy, 1998). Sosyal-bilişsel teoriye dayalı öğretmen yeterliği, verilen eğitimsel amaçlara ulaşmak için gerekli olan aktiviteleri gerçekleştirme, organize etme, planlama yeteneği ile ilgili öğretmenin kişisel inançları olarak kavramsallaştırılmıştır (Skaalvik ve Skaalvik, 2009).

Öğretmen özyeterliği, öğretmenin sınıf içi kararlarını ve davranışlarını doğrudan veya dolaylı yoldan etkileyen en güçlü yordayıcı olarak iddia edilmiştir (Pajares, 1992). Yüksek özyeterlik inancına sahip öğretmenler, öğretim sırasında herhangi bir zorlukla karşılaştıklarında öğretimi yarıda bırakmazlar ve görevlerini başarıyla yerine getirmek için değişik yöntemler geliştirebilirler (Woolfolk Hoy ve Burke-Spero, 2005). Ashton ve Webb (1986), yüksek öz-yeterlik inancına sahip olan öğretmenlerin, tüm öğrencilerin öğrenebileceklerine inanma eğiliminde olduklarını ve bu ögretmenlerin sınıflarını da bunu teminat altına alma yönünde geliştirdiklerini belirtmektedir. Öğretmenlerin öz-yeterlilik inançları, öğrencilerin güdülenmesini etkilediğinden öğrencilerin tutumlarının olumlu olmasını ve akademik başarısının da önemli derecede artmasına neden olmaktadır. Bunun yanı sıra, güçlü bir öz-yeterlik inancına sahip öğretmenlerin iyi bir planlama yapma ve daha iyi öğretmek için gayret gösterme eğiliminde oldukları bilinmektedir (Eker, 2014). Aynı zamanda, bu öğretmenlerin, öğrenci merkezli öğretim stratejileri uygulamaya ve hümanist sınıf yönetimi yaklaşımlarını kullanmaya eğilimli olduğu görülmektedir (Gibson ve Dembo, 1984; Henson, 2001; Savran-Gencer ve Çakıroğlu, 2007; Wertheim ve Leyser, 2002; Çapa Aydın, Uzuntiryaki Kondakçı, Yeliz Temli, Ayşegül Tarkın, 2013).

Öğretmen özyeterliğini etkileyen faktörler hakkında bilgi sahibi olmak, öğretmenlerin yeterlik yargılarını güçlendirmek ve mesleki gelişimlerine katkı sağlamak bakımında önemlidir. Bandura'nın ileri sürdüğü özyeterlik ve başarı arasındaki ilişkiye dayanarak, özyeterliği yüksek olan öğretmenlerin 
daha etkili bir öğretim gerçekleştireceği söylenebilir. Dolayısıyla, öğretmen özyeterliğini etkileyen faktörler bilinirse, öğretmenlerin özyeterliliklerini geliştirecek mesleki destekler sağlanabilir ve öğretim süreci daha etkili hale gelebilir. Bu bağlamda bu araştırmanın amacı, Milli Eğitim Bakanlığı'na bağlı devlet okullarından ilkokullarda görev yapan sınıf öğretmenlerinin özyeterlik düzeylerini belirlemektir. Araştırmada, aşağıdaki sorulara cevap aranmıştır.

1. Branş öğretmenlerinin özyeterlik düzeyleri nedir?

2. Branş öğretmenlerinin özyeterlik düzeyleri; cinsiyet, branş, kıdem, eğitim düzeyleri, okuldaki görev süresi, öğretmen sayısı, çalıştıkları yerleşim yeri ve okuldaki öğrenci sayısı gibi değişkenlere göre anlamlı farklılık göstermekte midir?

3. Branş öğretmenlerinin özyeterlik düzeyleri arasında; sınıf yönetimine yönelik özyeterlik, öğrenci katılımına yönelik özyeterlik ve öğretim stratejilerine yönelik özyeterlik alt boyutları arasında anlamlı bir ilişki var mıdır?

\section{YÖNTEM}

$\mathrm{Bu}$ araştırma anlık tarama modelindedir. Anlık tarama araştırmaları, belli bir zamanda mevcut durumun var olduğu şekliyle betimlenmesi amacıyla yürütülen çalışmalar olarak tanımlanmaktadır (Büyüköztürk, 2016, s.179). Tarama modelleri, geçmişte ya da halen var olan bir durumu var olduğu şekliyle betimlemeyi amaçlar. Araştırmaya konu olan olay, birey ya da nesne, kendi koşulları içinde ve olduğu gibi tanımlanmaya çalışılır (Karasar, 2009, s. 77).

Evren ve Örneklem

Araştırmanın evrenini, 2017-2018 eğitim öğretim yılında, Elazı̆̆ merkez ve ilçelerin merkezindeki ortaokullarda görev yapan toplam 1602; Örneklemini ise, basit tesadüfi örnekleme yolu ile belirlenen toplam 360 öğretmen oluşturmaktadır. Çalışmaya katılan öğretmenlerin demografik özellikleri incelendiğinde araştırmaya katılan erkek öğretmenlerin sayısı 174 (\%48,3), kadın öğretmenlerin sayısı ise $186(\% 51,7)$ 'dır. Branş değişkenine göre, sosyal bilimler branşındaki öğretmen sayısı 157 (\%43,6), fen bilimleri branşındaki öğretmen sayısı $139(\% 38,6)$ ve özel yetenek branşındaki öğretmen sayısı 64 (\%17,8)'tür. Kıdem değişkenine göre, 1-5 yıl kıdemi olan öğretmen sayısı 105 (\%29,2), 6-10 yıl 105 kişi (\%29,2), 11-15 y1l 49 kişi (\%13,6), 16-20 y1l 55 (\%15,3) ve 21 yıl ve üstü $46(\% 12,8)$ 'dır. Eğitim düzeyi değişkenine göre, lisans mezunu öğretmenlerinin sayısı 326 $(\% 90,6)$ iken lisans üstü mezunların sayısı $34(\% 9,4)$ 'tür. Okuldaki görev süresi değişkenine göre, okuldaki görev süresi 1 yıl olan öğretmen sayısı 84 (\%23,3), görev süresi 2 yıl olan 54 kişi $(\% 15,0)$, görev süresi 3 yıl olan 46 kişi $(12,8)$, görev süresi 4 yıl olan 61 kişi $(\% 16,9)$ ve görev süresi 5 yıl ve üstü olan öğretmen sayısı ise 115 (\%31,9)'dir. Okuldaki öğretmen sayısı değişkenine göre, 11-19 arası öğretmenin görev yaptığı okulda 70 öğretmen $(\% 19,4), 20-29$ arası öğretmenin görev yaptığ1 okulda 64 öğretmen $(\% 17,8)$ ve 30 ve üstü öğretmenin görev yaptığı okulda 226 öğretmen $(\% 62,8)$ görev yapmaktadır. Öğretmenlerin 248'i $(\% 68,9)$ il merkezinde ve 112 'si de $(\% 31,1)$ ilçe merkezinde 
çalışmaktadır. Öğrenci sayısı 100-500 arasında olan okullarda 107 öğretmen (\%29,7), öğrenci sayıs1 501-999 arasında olan okullarda 112 öğretmen (\%31,1), öğrenci sayıs1 1000-1499 arasında olan okullarda 96 öğretmen $(\% 26,7)$ ve öğrenci sayısı 1500-2000 arasında olan okullarda 131 öğretmen $(\% 12,5)$ görev yapmaktadır.

Veri Toplama Aracı

Araştırmada veri toplama aracı olarak, Orijinali Tschannen-Moran ve Hoy (2001) tarafından geliştirilen ve Çapa, Çakıroğlu, Sarıkaya (2005) tarafından Türkçe’ye uyarlanan Öğretmen ÖzYeterlik Ölçeği kullanılmıştır. Araştırmacılar, 628 öğretmen adayı ile yaptıkları çalışmada ölçeğin güvenirlik katsayısını .93 olarak tespit etmişlerdir. Bu çalışmada ise ölçeğin güvenirlik katsayısı .96 olarak hesaplanmıştır. Ölçek likert tipinde "yetersiz-1" den “çok yeterli-9"ye doğru derecelendirilmiştir. Ölçekten alınacak en düşük puan 24, en yüksek puan ise 216 ' dır. Ölçekten alınan düşük puan, düşük öz yeterlik inancına, yüksek puan ise yüksek öz yeterlik inancını ifade etmektedir. Ölçüt aralığı 1-2 yetersiz;3-4 çok az yeterli; 5-6 biraz yeterli; 7-8 oldukça yeterli; 9 çok yeterli şeklindedir. Öğretmen Öz-Yeterlik Ölçeği maddelerinin ortalama puanları değerlendirilirken kullanılan puan aralıkları şunlardır: 1.00-2.59 Yetersiz; 2.60-4.19 Çok az yeterli; 4.20-5.79 Biraz yeterli;5.80-7.39 Oldukça yeterli; 7.40-9.00 Çok yeterli. Turkish version of the Teachers' Sense of Efficacy Scale - Türkçe Öğretmen Özyeterlik Ölçeği (TTSES) öğrenci katılımında yeterlik (8 madde), öğretimsel stratejilerde yeterlik (8 madde), sınıf yönetiminde yeterlik (8) olmak üzere 3 alt boyuttan ve 24 maddeden oluşmaktadır. Araştırmacı ölçeğin orijinalindeki "çalışması zor öğrencilere ulaşmayı ne kadar başarabilirsiniz?” sorusunu “çalışma isteği az olan öğrencilerin bu isteğini artırmada ne kadar yeterlisiniz?” şeklinde, diğer maddelerin yüklemlerini de birlikteliği sağlamak amacıyla "yeterlisiniz" olarak değiştirmiştir. Ayrıca ölçeğin orjinaline iki adet daha soru eklemiş ve ölçek toplam 26 maddeden oluşmuştur. Ölçek orijinalinde birinci boyut "sınıf yönetimine yönelik özyeterlik", ikinci boyut "öğrenci katılımına yönelik özyeterlik” üçüncü boyut ise, "öğretim stratejilerine yönelik özyeterlik" olarak isimlendirilmiştir. Veri toplama araçlarının yapı geçerliğini sağlamak için araştırmacı tarafından açıklayıcı faktör analizi yapılmıştır. Faktör analizi, aynı yapıyı ya da niteliği ölçen değişkenleri bir araya toplayarak ölçmeyi az sayıda faktör ile açıklamayı amaçlayan bir istatistiksel tekniktir (Büyüköztürk, 2009, s. 123). Ölçeğin faktörleri için Cronbach’s Alfa güvenirlik katsayısı, sınıf yönetimine yönelik özyeterlik alt boyutu için 0.90, öğrenci katılımına yönelik özyeterlik alt boyutu için 0.91 , öğretim stratejilerine yönelik özyeterlik alt boyutu için 0.92 şeklindedir.

\section{Verilerin çözümü}

Veriler, SPSS for Windows 21 programı kullanılarak analiz edilmiştir. Branş öğretmenlerinin demografik özelliklerini (cinsiyet, kıdem, eğitim düzeyleri, okuldaki görev süresi, öğretmen sayısı, çalıştıkları yerleşim yeri ve okuldaki öğrenci sayısı) belirlemek için frekans ve yüzde değerleri kullanılmıştır. Sınıf öğretmenlerinin özyeterlik düzeylerini belirlemek için aritmetik ortalama ve standart sapma teknikleri kullanılmıştır. Cinsiyet, eğitim düzeyi ve çalışılan yerleşim yeri değişkenleri 
açısından belirtilen görüşler arasında anlamlı bir farklılık olup olmadığını belirlemek için bağımsız gruplar t-Testi yapılmıştır. Ayrıca, kıdem, okuldaki görev süresi, okuldaki öğretmen sayısı ve okuldaki öğrenci sayısı gibi değişkenler açısından görüşleri arasında anlamlı bir farklılık olup olmadığını belirlemek için Tek Yönlü Varyans Analizi (ANOVA) yapılmış, grup varyanslarının eşit olduğu durumlarda, ortalama puanlarının çoklu karşılaştırılmasında kullanılan LSD testi ile hangi grupların ortalamaları arasında fark olup olmadığı sınanmıştır. Uygulanan testlerin anlamlılık düzeyi .05 olarak alınmıştır.

\section{BULGULAR}

$\mathrm{Bu}$ bölümde, branş öğretmenlerinin özyeterlik düzeylerini belirlemek için uygulanan ölçekten elde edilen bulgulara ve yorumlara yer verilmiştir.

1. Branş öğretmenlerinin özyeterlik düzeyleri nedir?

Tablo 1. Branş öğretmenlerinin özyeterlik düzeyleri

\begin{tabular}{lll}
\hline \multicolumn{1}{c}{ Alt boyutlar $\quad \mathrm{n}=360$} & $\overline{\mathrm{X}}$ & $\mathrm{SS}$ \\
\hline 1. Sinıf yönetimine yönelik özyeterlik & 7,21 & 1,11 \\
\hline 2. Öğrenci katılımına yönelik özyeterlik & 7,10 & 1,08 \\
\hline 3. Öğretim stratejilerine yönelik özyeterlik & 7,20 & 1,14 \\
\hline 4. Toplam & 7,17 & 1,07 \\
\hline
\end{tabular}

Tablo 1'de de görüldüğü gibi, branş öğretmenlerinin özyeterlik düzeyleri, sınıf yönetimine yönelik özyeterlik alt boyutunda $(\bar{x}=7,21)$, ögrenci katılımına yönelik özyeterlik alt boyutunda $(\bar{X}=7,10)$, öğretim stratejilerine yönelik özyeterlik alt boyutunda $(\bar{X}=7,20)$ ve ölçeğin tamamında $(\overline{\mathrm{X}}=7,17)$ oldukça yeterli düzeyindedir.

2. Branş öğretmenlerinin özyeterlik düzeyleri cinsiyet, eğitim seviyesi ve çalıştıkları yerleşim yeri değişkenlerine göre anlamlı farklılık göstermekte midir? Alt amacına yönelik analiz sonuçları Tablo 2'de verilmiştir.

Tablo 2. Branş öğretmenlerinin özyeterlik düzeylerine ilişkin t-Testi sonuçları

\begin{tabular}{|c|c|c|c|c|c|c|c|c|}
\hline \multirow{2}{*}{ Alt Boyutlar } & & \multirow{2}{*}{$\mathbf{N}$} & \multirow{2}{*}{$\bar{X}$} & \multirow{2}{*}{ SS } & \multicolumn{2}{|c|}{ Levene } & \multirow{2}{*}{$\mathbf{t}$} & \multirow{2}{*}{$\mathbf{p}$} \\
\hline & & & & & $\mathbf{F}$ & $\mathbf{p}$ & & \\
\hline & Cinsiyet & & & & & & & \\
\hline \multirow{2}{*}{$\begin{array}{l}\text { 1.Sınıf yönetimine yönelik } \\
\text { özyeterlik }\end{array}$} & Erkek & 174 & 7,34 & 1,09 & ,106 & ,745 & 2,261 &, $024 *$ \\
\hline & Kadın & 186 & 7,08 & 1,11 & & & & \\
\hline \multirow{2}{*}{$\begin{array}{l}\text { 2.Öğrenci katılımına } \\
\text { yönelik özyeterlik }\end{array}$} & Erkek & 174 & 7,21 & 1,06 & ,025 & ,875 & 1,944 & ,053 \\
\hline & Kadın & 186 & 6,99 & 1,09 & & & & \\
\hline \multirow{2}{*}{$\begin{array}{l}\text { 3.Öğretim stratejilerine } \\
\text { yönelik özyeterlik }\end{array}$} & Erkek & 174 & 7,37 & 1,10 & ,016 & ,901 & 2,844 &, $005^{*}$ \\
\hline & Kadın & 186 & 7,04 & 1,15 & & & & \\
\hline \multirow[t]{2}{*}{ 4. Toplam } & Erkek & 174 & 7,31 & 1,04 & ,023 & ,879 & 2,458 & ,014* \\
\hline & Kadın & 186 & 7,03 & 1,07 & & & & \\
\hline \multirow{2}{*}{$\begin{array}{l}\text { 1.Sınıf yönetimine yönelik } \\
\text { özyeterlik }\end{array}$} & Lisans & 326 & 7,20 & 1,11 & ,031 & ,861 &,- 184 & ,854 \\
\hline & Lisans üstü & 34 & 7,24 & 1,08 & & & & \\
\hline
\end{tabular}




\begin{tabular}{|c|c|c|c|c|c|c|c|c|}
\hline \multirow{2}{*}{$\begin{array}{l}\text { 2.Öğrenci katılımına } \\
\text { yönelik özyeterlik }\end{array}$} & Lisans & 326 & 7,09 & 1,10 & \multirow[t]{2}{*}{462} & \multirow[t]{2}{*}{,497 } & \multirow[t]{2}{*}{,- 671} & \multirow[t]{2}{*}{, 502} \\
\hline & Lisans üstü & 34 & 7,22 & ,94 & & & & \\
\hline \multirow{2}{*}{$\begin{array}{l}\text { 3.Öğretim stratejilerine } \\
\text { yönelik özyeterlik }\end{array}$} & Lisans & 326 & 7,18 & 1,14 & \multirow[t]{2}{*}{,569 } & \multirow[t]{2}{*}{,451 } & \multirow[t]{2}{*}{$-1,078$} & \multirow[t]{2}{*}{,282 } \\
\hline & Lisans üstü & 34 & 7,40 & 1,08 & & & & \\
\hline \multirow[t]{2}{*}{ 4. Toplam } & Lisans & 326 & 7,15 & 1,08 & \multirow[t]{2}{*}{,702 } & \multirow[t]{2}{*}{,403 } & \multirow[t]{2}{*}{,- 693} & \multirow[t]{2}{*}{,489 } \\
\hline & Lisans üstü & 34 & 7,29 & ,95 & & & & \\
\hline \multirow{2}{*}{$\begin{array}{l}\text { 1. Sınıf yönetimine } \\
\text { yönelik özyeterlik }\end{array}$} & İl merkezi & 248 & 7,21 & 1,14 & \multirow[t]{2}{*}{,263 } & \multirow[t]{2}{*}{,609 } & \multirow[t]{2}{*}{,162 } & \multirow[t]{2}{*}{,871 } \\
\hline & İlçe merkezi & 112 & 7,19 & 1,04 & & & & \\
\hline \multirow{2}{*}{$\begin{array}{l}\text { 2. Öğrenci katılımına } \\
\text { yönelik özyeterlik }\end{array}$} & İl merkezi & 248 & 7,15 & 1,10 & \multirow[t]{2}{*}{,023 } & \multirow[t]{2}{*}{,878 } & \multirow[t]{2}{*}{1,281} & \multirow[t]{2}{*}{,201 } \\
\hline & İlçe merkezi & 112 & 6,99 & 1,05 & & & & \\
\hline \multirow{2}{*}{$\begin{array}{l}\text { 3. Öğretim stratejilerine } \\
\text { yönelik özyeterlik }\end{array}$} & İl merkezi & 248 & 7,27 & 1,13 & \multirow[t]{2}{*}{, 012} & \multirow[t]{2}{*}{,912 } & \multirow[t]{2}{*}{1,721} & \multirow[t]{2}{*}{,086 } \\
\hline & İlçe merkezi & 112 & 7,05 & 1,13 & & & & \\
\hline \multirow[t]{2}{*}{ 4. Toplam } & İl merkezi & 248 & 7,21 & 1,08 & \multirow[t]{2}{*}{,001 } & \multirow[t]{2}{*}{,977 } & \multirow[t]{2}{*}{1,136} & \multirow[t]{2}{*}{,257 } \\
\hline & İlçe merkezi & 112 & 7,07 & 1,03 & & & & \\
\hline
\end{tabular}

Tablo 2'de görüldüğü gibi, cinsiyet, eğitim düzeyi ve öğretmenlerin çalıştıkları yerleşim yeri değişkenlerinden sadece cinsiyet değişkeninde, branş öğretmenlerinin görüşlerine göre, sinıf yönetimine yönelik özyeterlik, öğretim stratejilerine yönelik özyeterlik alt boyutlarında ve ölçeğin tamamında anlamlı bir fark çıkmıştır. Erkek öğretmenlerin bu alt boyutlarda ve ölçeğin tamamında özyeterlik düzeyleri kadın öğretmenlere göre daha yüksektir. Eğitim seviyesi ve öğretmenlerin çalıştıkları yerleşim yeri değişkenlerine göre alt boyutlarda ve ölçeğin tamamında branş öğretmenlerinin görüşleri arasında anlamlı farklılık çıkmamıştır.

Branş öğretmenlerinin okuldaki öğrenci sayısı değişkenine göre özyeterlik düzeylerine yönelik yapılan ANOVA sonuçları Tablo 3’te verilmiştir.

Tablo 3. Okuldaki öğrenci sayısı değişkenine göre ANOVA sonuçları

\begin{tabular}{|c|c|c|c|c|c|c|c|c|c|}
\hline Değişkenler & $\mathrm{N}$ & $\bar{X}$ & $\begin{array}{l}\text { Varyansın } \\
\text { kaynağ1 }\end{array}$ & $\begin{array}{l}\text { Kareler } \\
\text { Toplamı }\end{array}$ & $\mathrm{sd}$ & $\begin{array}{l}\text { Kar } \\
\text { Ort. }\end{array}$ & $\mathrm{F}$ & $\mathrm{P}$ & $\begin{array}{l}\text { Fark } \\
\text { LSD }\end{array}$ \\
\hline \multicolumn{10}{|c|}{ Okuldaki öğrenci sayısı } \\
\hline \multicolumn{10}{|c|}{ 1. Sinıf yönetimine yönelik özyeterlik } \\
\hline $1.100-500$ öğrenci & 107 & 7,19 & Gruplararası & 9,686 & 3 & 3,229 & 2,643 & \multirow[t]{4}{*}{,049 } & \multirow{4}{*}{$2-3,4$} \\
\hline 2.501-999 öğrenci & 112 & 7,00 & Gruplariçi & 434,957 & 356 & \multirow[t]{3}{*}{1,222} & & & \\
\hline 3.1000-1499 öğrenci & 96 & 7,36 & Toplam & 444,644 & 359 & & & & \\
\hline 4.1500-2000 öğrenci & 45 & 7,45 & & & & & & & \\
\hline
\end{tabular}

Tablo 3’te de görüldüğü gibi, sınıf yönetimine yönelik özyeterlik alt boyutunda, öğrenci sayıs1 501-999 arasında olan okullarda görev yapan branş öğretmenlerinin özyeterlik düzeyleri ile öğrenci sayıs1 1000-1499 ve 1500-2000 arasında olan okullarda görev yapan öğretmenlerin özyeterlik düzeyleri arasında LSD testine göre anlamlı bir fark ortaya çıkmıştır. Öğrenci sayısı 501-999 arasında olan okullarda görev yapan öğretmenlerin özyeterlik düzeyleri, öğrenci sayıs1 1000-1499 ve 15002000 arasında olanlara göre daha düşüktür. Branş, kıdem yıl1, okuldaki öğretmen sayısı ve okuldaki görev süresi değişkenlerine yönelik yapılan ANOVA analizi sonuçlarına göre, branş öğretmenlerinin özyeterlik düzeyleri arasında anlamlı bir fark çıkmamıştır. 
3. Branş öğretmenlerinin özyeterlik düzeyleri arasında, sınıf yönetimine yönelik özyeterlik, öğrenci katılımına yönelik özyeterlik ve öğretim stratejilerine yönelik özyeterlik alt boyutları arasında anlamlı bir ilişki var mıdır? Alt amacına yönelik yapılan analize ait bulgular Tablo 4’te verilmiştir.

Tablo 4. Alt Boyutlara Göre yöneticilerin dağıtılmış liderlik düzeyleri Arasındaki İlişki

\begin{tabular}{|c|c|c|c|c|}
\hline & & 1. & 2. & 3. \\
\hline \multirow{3}{*}{$\begin{array}{l}\text { 1.Sınıf yönetimine yönelik } \\
\text { özyeterlik }\end{array}$} & Pearson Correlation & 1 &, $907 * *$ &, $871 * *$ \\
\hline & Sig. (2-tailed) & & ,000 & , 000 \\
\hline & $\mathrm{N}$ & 360 & 360 & 360 \\
\hline \multirow{3}{*}{$\begin{array}{l}\text { 2.Öğrenci katılımına } \\
\text { yönelik özyeterlik }\end{array}$} & Pearson Correlation & & 1 & ,880** \\
\hline & Sig. (2-tailed) & & & , 000 \\
\hline & $\mathrm{N}$ & & 360 & 360 \\
\hline \multirow{3}{*}{$\begin{array}{l}\text { 3.Öğretim stratejilerine } \\
\text { yönelik özyeterlik }\end{array}$} & Pearson Correlation & & & 1 \\
\hline & Sig. (2-tailed) & & & \\
\hline & $\mathrm{N}$ & & & 360 \\
\hline
\end{tabular}

**Correlation is significant at the 0.01 level (2-tailed).

Tablo 4'te görüldüğü gibi, sınıf yönetimine yönelik özyeterlik ile öğrenci katılımına yönelik özyeterlik arasında ( $r=0,859, \mathrm{p}=0.00)$ yüksek ve pozitif düzeyde bir korelasyon olduğu görülmektedir. Buna göre, sınıf yönetimine yönelik özyeterlik arttıkça öğrenci katılımına yönelik özyeterlik düzeyinin arttı̆̆ı söylenebilir. Determinasyon katsayısı $\left(r^{2}=0.82\right)$ dikkate alındığında, sınıf yönetimine yönelik özyeterlik düzeyinin toplam varyansının \%82'sinin öğrenci katılımına yönelik özyeterlik düzeyinden kaynaklandığı söylenebilir.

Sınıf yönetimine yönelik özyeterlik ile öğretim stratejilerine yönelik özyeterlik arasında $(\mathrm{r}=0,871, \mathrm{p}=0.00)$ yüksek ve pozitif düzeyde bir korelasyon olduğu görülmektedir. Buna göre, sinıf yönetimine yönelik özyeterlik arttıça öğretim stratejilerine yönelik özyeterlik düzeyinin arttı̆̆ söylenebilir. Determinasyon katsayısı $\left(r^{2}=0.75\right)$ dikkate alındığında, sınıf yönetimine yönelik özyeterlik düzeyinin toplam varyansının \%75'inin öğretim stratejilerine yönelik özyeterlik düzeyinden kaynaklandığı söylenebilir.

Öğrenci katılımına yönelik özyeterlik ile öğretim stratejilerine yönelik özyeterlik arasında $(\mathrm{r}=0,880, \mathrm{p}=0.00)$ yüksek ve pozitif düzeyde bir korelasyon olduğu görülmektedir. Buna göre, öğrenci katılımına yönelik özyeterlik arttıkça öğretim stratejilerine yönelik özyeterlik düzeyinin arttı̆̆ söylenebilir. Determinasyon katsayısı $\left(r^{2}=0.77\right)$ dikkate alındığında, öğrenci katılımına yönelik özyeterlik düzeyinin toplam varyansının \%77'sinin öğretim stratejilerine yönelik özyeterlik düzeyinden kaynaklandığı söylenebilir. 


\section{TARTIŞMA VE SONUÇ}

Araştırmaya katılan branş öğretmenlerinin bütün alt boyutlarda ve ölçeğin tamamında mesleki öz yeterlik düzeyleri oldukça yeterlidir. Ayra ve Kösterelioğlu (2015) tarafından yapılan araştırmanın bulgularına göre, sınıf öğretmenlerinin öz yeterlik algılarının iyi düzeyde olduğu, en düşük öz yeterlik algıları öğrenci katılımını sağlama boyutunda iken; en yüksek öz yeterlik algılarının öğretim stratejilerini kullanma alt boyutunda olduğu bulgusuna erişilmiştir. Bulgular benzerlik göstermektedir. Eker (2014) tarafindan yapılan araştırmadan elde edilen bulgulara göre, ilkokullarda görev yapan sınıf öğretmenlerinin genel öz-yeterlik inanç düzeylerinin "yeterli" olduğu bulunmuştur. Ölçeğin, öğrencilerin derslere aktif katılımını sağlama alt boyutunda öğretmenlerin öz-yeterlik inançları "orta düzeyde yeterli”, öğretim stratejilerini kullanma alt boyutunda ve sınıf yönetiminde öz-yeterlik inanç alt boyutunda ise kendilerini “yeterlie gördükleri bulunmuştur. Araştırma bulguları karşılaştırıldığında araştırma yapılan grupların farklılıkları nedeniyle farklılık göstermiş olabilir. Çimen (2007) tarafından ilköğretim okulu öğretmenleri üzerinde yapılan araştırmanın bulgularına göre, öğretmenlerin her üç alt boyutta da kendilerini oldukça yeterli gördükleri sonucu bulunmuştur. Bulgular örtüşmektedir. Öğretmenlerin öz-yeterliliklerini belirlemeye yönelik yapılan araştırmalar incelendiğinde (Ekici, 2006; Özata, 2007; Gençtürk, 2008; Turcan, 2011; Barut, 2011; Benzer, 2011) bu araştırmaların bulgularına göre öğretmenlerin özyeterlik düzeylerinin yeterli olduğu belirlenmiştir. Bu araştırmanın bulguları ile farklılık bulunmaktadır. Babaoğlan ve Korkut (2010) tarafindan yapılan araştırma bulgularına göre, sınıf öğretmenlerinin öz yeterlik inançlarının oldukça yüksek düzeyde olduğu belirlenmiştir. Zararsız (2012), tarafından yapılan araştırma bulgularına göre, öğretmenler genel öz yeterlik ve alt boyutlarında kendilerini oldukça yeterli hissetmektedirler. Bulgular benzemektedir. Yılmaz ve Çokluk-Bökeoğlu (2008) da öğretmenlerin öz yeterlik inançlarının “çok yüksek” düzeyde olduğunu ortaya koymuşlardır. Güven ve Cevher (2005), Kars (2007) ve Korkmaz (2007) da öğretmenlerin kendilerini yüksek düzeyde yeterli olarak algıladıklarını belirlemiştir. Aktağ ve Walter (2005) tarafindan yürütülen çalışmada öğretmen adaylarının yeterlik algıları iyi düzeyde bulunmuştur. Bulgular benzemektedir.

Cinsiyet değişkenine göre, sınıf yönetimine yönelik özyeterlik, öğretim stratejilerine yönelik özyeterlik alt boyutlarında ve ölçeğin tamamında erkek öğretmenlerin özyeterlik düzeyleri kadın öğretmenlere göre daha yüksektir. Yüksek öz yeterlik inancı taşıma, büyük ölçüde kendine güven ile özdeşleştirilebilir. Diğer bir çok konuda da kendilerine güvenme davranışı, daha güçlü benlik duygusu taşıdığını gösterme çabası ile erkeklerin bayanlara göre benlik duygularının biraz daha yüksek olduğuna ilişkin bir çok çalışma mevcuttur (Morgil, Seçken ve Yücel, 2004; Bandura and Schunk, 1981; Betz and Hackett, 1981; Brophy, 1985; Jones and Wheatley, 1990; Sadker and Sadker, 1994). Brandon (2000) ilkokul öğretmenleri ile yapmış olduğu çalışmada, erkek öğretmenlerin özyeterliklerinin kadın öğretmenlerden daha yüksek olduğunu bulmuştur. Gruplar farklı olsa da bulgular 
benzerdir. Gençtürk ve Memiş (2010) tarafından yapılan araştırma bulgularına göre, kadın ve erkek öğretmenlerin genel öz-yeterlik ve alt boyutlarında kendilerini oldukça yeterli algıladıkları, kadın öğretmenlerin genel öz-yeterlik ve öğretimsel stratejilerde, erkek öğretmenler ise öğrenci katılımında yeterlik ve sınıf yönetiminde yeterlik alanlarında kendilerini karşı cinslerine göre daha yeterli algılamaktadır. Bulgular kısmen benzerdir. Yüksek yeterliğe sahip öğretmenlerin aksine, düşük yeterliğe sahip öğretmenler eğitimde daha geleneksel yöntemler kullanmaktadırlar. Kontrollü bir öğretim ortamı oluşturmak için sert yönetim stratejileri kullanmaya eğilimlidirler (Collins vd., 2002, s. 6). Öğretmen yeterliği ile ilgili birçok araştırma, öğretmenlerin yeterliklerine daha az güvenmelerinin problemli olduğunu göstermiştir. Örneğin, Tschannen-Moran ve arkadaşları (1998, s. 234), "Düşük yeterlik hissi daha az çaba, kolayca pes etme anlamına gelir ki bunlar kötü öğrenci yani kötü öğretim çıktılarına neden olur ve bunun sonucu olarak yeterlik azalır." şeklinde ifade etmişlerdir. Düşük yeterlik, öğretmenlerin faaliyetlerini, çabalarını ve dirençlerini etkilemektedir. Düşük yeterliğe sahip öğretmenler, yeteneklerini aştığına inandıkları faaliyetleri planlamaktan kaçınabilir, öğrenmede zorluk çeken öğrencilerle uğraşmaz, materyal bulmada çok az çaba harcar, öğrencilerin daha iyi anlamasını sağlayacak yollar aramazlar (Schunk, 1991, s. 224). Wheatly (2002, s. 6-7), yeteneklerine daha az güvenen öğretmenlerin öğrenci çıktılarına çok fazla müdahale edilemeyeceğine ya da kişisel olarak bu yeteneğe sahip olmadıklarına inandıklarını ifade etmiştir (Gençtürk ve Memiş, 2010, s. 1039). Üstüner, Demirtaş, Cömert ve Özer (2009) tarafindan yapılan araştırmanın bulgularına göre, ortaöğretim öğretmenlerinin öz yeterliliklerine ilişkin algılarının cinsiyet değişkenine göre anlamlı biçimde farklılaşmadığı, araştırmaya katılan kadın ve erkek öğretmenlerin, kendilerini "orta" düzeyde yeterli olarak algıladıkları belirlenmiştir. Araştırma yapılan grupların farklılığı bulguların anlamlılığına ve düzeyine de etki etmiş ve farklılaştırmış olabilir. Telef (2011) tarafindan yapılan araştırma bulgularına göre de, öz-yeterliğin alt boyutlarından öğrenci katılımını sağlama yeterliği, sınıf yönetimi yeterliği ve öğretim stratejilerini kullanma yeterliği ve genel öz-yeterlik boyutunda cinsiyete göre farklılık belirlenmemiştir. Gür, Çakıoğlu ve Çapa- Aydın (2012) tarafından yapılan, sınıf, fen ve matematik öğretmenlerinin özyeterliklerini yordayan değişkenlerin incelenmesi adlı araştırmanın bulgularına göre de, cinsiyetin öğretmenlerin öğretim stratejilerine, sınıf yönetimine ve öğrenci katılımına yönelik özyeterliklerini etkilemediği belirlenmiştir. Bulgular farklıdır. Brandon’un (2000) ilkokul öğretmenleri ile yapmış olduğu çalışmada, erkek öğretmenlerin öz-yeterliklerinin kadın öğretmenlerden daha yüksek olduğu bulunmuştur. Bulgular bu araştırma bulguları ile aynıdır. Coşkun'un (2010) tarafından yapılan araştırma bulgularına göre, erkek din kültürü ve ahlak bilgisi öğretmenlerinin öz yeterlik algıları (öğrenci katılımını sağlama, sınıf yönetimi, öğretim stratejileri alt boyutunda), kadın öğretmenlere göre daha yüksek ve anlamlıdır. Bulgular bu araştırma bulguları ile aynidir.

Eğitim düzeyi değişkenine göre, branş öğretmenlerinin özyeterlik düzeyleri arasında anlamlı bir fark çıkmamıştır. Telef (2011) tarafindan yapılan araştırma bulgularına göre de, öz-yeterliğin alt boyutlarından öğrenci katılımını sağlama yeterliği, sınıf yönetimi yeterliği, öğretim stratejilerini 
kullanma yeterliği ve genel öz-yeterlik boyutunda eğitim düzeyine göre farklılık belirlenmemiştir. Bulgular benzerdir. Umaz'ın (2010) tarafından yapılan araştırmanın bulgularına göre, lisansüstü mezunu olan ilköğretim okulu öğretmenlerinin lisans mezunu öğretmenlere göre öz yeterlik düzeyleri anlamlı derecede yüksek çıkmıştır. Bulgular farklıdır. Okuldaki görev süresi değişkenine göre, branş öğretmenlerinin özyeterlik düzeyleri arasında anlamlı bir fark çıkmamıştır. Türk (2008) tarafindan yapılan araştırmanın bulgularına göre, öğretmenlerin öz yeterlik düzeylerinin, okulda çalışılan yıla göre farklılık gösterdiği ortaya çıkmıştır. Bulgular farlıdır.

Çalıştıkları yerleşim yeri değişkenine göre, branş öğretmenlerinin özyeterlik düzeyleri arasında anlamlı bir fark çıkmamıştır. Babaoğlan ve Korkut (2010) tarafından yapılan araştırma bulgularına göre de, şehir merkezindeki okullarda görev yapan öğretmenlerin, köydeki ve ilçedeki okullarda görev yapan öğretmenlere göre öz yeterlik inançları daha yüksek çıkmıştır. Yine ilçedeki okullarda görev yapan öğretmenlerin, köydeki okullarda çalışan öğretmenlere göre öz yeterlik inançları daha yüksek çıkmıştır.

Kıdem değişkenine göre, branş öğretmenlerinin özyeterlik düzeyleri arasında anlamlı bir fark çıkmamıştır. Üstüner, Demirtaş, Cömert ve Özer (2009) tarafından yapılan araştırmanın bulgularına göre, ortaöğretim öğretmenlerinin öz yeterliliklerine ilişkin algılarının kıdem değişkenine göre anlamlı biçimde farklılaşmadığı belirlenmiştir. Babaoğlan ve Korkut (2010) tarafindan yapılan araştırma bulgularına göre de, öğretmenlerin öz yeterlik inançları hizmet yıllarına göre anlamlı farklılık göstermemektedir. Yılmaz ve Çokluk-Bökeoğlu (2008) tarafindan yapılan araştırma bulguları da bu bulguyu desteklemektedir. Ekici (2006) ve Ercan (2007) da hizmet yıllarına göre öğretmenlerin öz yeterlik inançlarının farklılık göstermediğini ortaya koymuşlardır. Tunacan'ın (2005) lise öğretmenleri ile yaptığı çalışmada, 11-15 yıl arası çalışan öğretmenlerin sınıf yönetimi yeterliği 1-5 yıllar arası çalışan öğretmenlerden daha yüksek olduğu bulunmuştur. Gençtürk (2008) 11 y1l ve daha fazla tecrübeye sahip ilköğretim öğretmenlerinin $1-5$ ve $6-11$ y1l tecrübeye sahip ilköğretim öğretmenlerinden daha yüksek öz-yeterliğe sahip olduklarını bulmuştur. Gençtürk ve Memiş (2010) tarafından yapılan araştırma bulgularına göre, kıdem değişkenin en çok öğrenci katılımında yeterlik algısı üzerinde en az ise öğretimsel stratejilerde yeterlik algısı üzerinde etkili olduğu bulunmuştur. Özellikle, 11 yıl ve daha fazla tecrübesi olan öğretmenler, bütün yeterlik alanlarında diğerlerinden anlamlı bir şekilde farklıdır. Tschannen-Moran \& Woolfolk-Hoy (2002, s. 6), tecrübeli öğretmenlerin zaman içerisinde etkili öğretimsel stratejiler ve sınıf yönetimi becerileri geliştirme imkânlarını bulduklarını ifade etmişlerdir. Campbell (1996), Tschannen-Moran, \& Woolfolk Hoy, (2002), Daughetry (2005) ve Say (2005)'ın çalışmalarında da kıdemin atmasıyla öz-yeterlik algısının arttığı sonucuna varılmıştır. Bunların aksine, yapılan bazı araştırmalarda (Celep 2002; Chacon, 2005; Çimen, 2007) kıdem ile öz-yeterlik algısı arasında herhangi bir fark bulunmamıştır.

Branş değişkenine göre, branş öğretmenlerinin özyeterlik düzeyleri arasında anlamlı bir fark çıkmamıştır. Memiş (2010) tarafından yapılan araştırma bulgularına göre, branş değişkeninin en çok 
öğrenci katılımında yeterlik algısını, en az ise sınıf yönetiminde yeterlik algısını etkilediği bulunmuştur. Okuldaki öğretmen sayısı değişkenine göre, branş öğretmenlerinin özyeterlik düzeyleri arasında anlamlı bir fark çıkmamıştır.

Sonuç olarak, branş öğretmenlerinin öğrencilerin çalışma isteklerini artırma, öğrencilerin eleştirel düşünme becerilerine destek olma, derslere az ilgi gösteren öğrencileri motive etme, derslerde başarılı olmalarına inandırma, öğrencilerin zor sorularına iyi cevap verebilme, sınıfta yapılan etkinliklerin düzenli yürümesini sağlama, öğrencileri en iyi şekilde değerlendirebilmelerini sağlayacak soru hazırlama, öğrencilerin sınıf kurallarına uymalarını sağlayabilme ve kendilerini hiçe sayan davranışlar gösteren öğrencilerle baş edebilme gibi öğrenci katılımına yönelik özyeterlikleri düzeyleri düşüktür çıkmıştır. Öğrenci sayısı az olan okullarda görev yapan öğretmenlerin özyeterlik düzeyleri, öğrenci sayısı fazla olan okullarda görev yapanlara göre daha düşüktür. Bu sonuçlara göre, ögretmenlerin sınıf yönetimini etkileyen mesleki nitelikleri arasında sayılabilen öğretim yöntem ve tekniklerinden yararlanma, etkili iletişim kurma, zamanı etkili kullanma, değerlendirme ve rehberlik yapma gibi konularda gerek hizmet içinde gerekse hizmet sonrasında yetiştirilmelerine sürdürülebilir bir eğitimin niteliği için gereken önem verilerek bu konularda nitelikli seminerler verilmelidir. Yüksek yetkinlik düzeyine sahip olan öğretmenlerin de sınıf içinde ortaya çıan istenmeyen davranışlarla başa çıkmada teşvik, mizah, dokunma, uyarma ve soru sorma gibi önleyici ve olumlu yöntemlere başvurmada daha etkili oldukları unutulmamalıdır.

\section{KAYNAKÇA}

Akbaş, A. ve Çelikkaleli, Ö. (2006). Sınıf Öğretmeni Adaylarının Fen Öğretimi Öz-Yeterlik İnançlarının Cinsiyet, Öğrenim Türü ve Üniversitelerine Göre İncelenmesi. Mersin Üniversitesi Ĕ̌itim Fakültesi Dergisi, 2 (6), 98-110.

Ayra, M. ve Kösterelioğlu, İ. (2015). Öğretmenlerin Yaşam Boyu Öğrenme Eğilimlerinin Mesleki Öz Yeterlik Algıları İle İlişkisi. NWSA-Education Sciences. $10 \quad$ (1), $17-$ 28.doi.org/10.12739/10.1.1C0630

Babaoğlan, E. ve Korkut, K. (2010). Sınıf Öğretmenlerinin Öz Yeterlik İnançları ile Sınıf Yönetimi Beceri Algıları Arasındaki İlişki. İnönü Üniversitesi Eğitim Fakültesi Dergisi, 11 (1), 1-19.

Bandura, A \& Schunk. (1981). Cultivating competence, self efficacy and intrinsic interest through self-motivation. Journal of Personality and Social Psychology, 41,586-598.

Bandura, A. (1986). Social foundation of thought and action: A social cognitive theory. Englewood Cliffs, NJ: Prentice Hall.

Bandura, A. (1997). Self-efficacy in changing societies. In Bandura, A. (Ed.) Exercise of personal and collective efficacy in changing societies (pp. 1-45). New York: Cambridge University Pres. 
Barut, E. (2011). İlköğretim 2. Kademe sosyal bilgiler öğretmenlerinin öz yeterliliklerinin çeşitli değişkenler açısından incelenmesi: Ankara ili örneği (Yayımlanmamış yüksek lisans tezi). Ömer Halis Demir Üniversitesi Sosyal bilimler enstitüsü, Niğde.

Benzer, F. (2011). İlköğretim ve Ortä̈ğretim Kurumlarında Görev Yapan Öğretmenlerin Öz Yeterlik Algılarının Analizi (Yayımlanmamış yüksek lisans tezi). Selçuk Üniversitesi Eğitim Bilimleri Enstitüsü, Konya.

Betz, N. E ve Hackett, G. (1981). The relationship of career-related self efficacy expectations to perceived career options in college women and men. Journal of Counseling Psychology, 28, 399-410.

Brandon, D. P. (2000). Self-efficacy: gender differences of prospective primary teachers. Research in Education, 64, 36-43.

Brophy, J. (1985). Interactions of Male and Female Students with Male and Female Teachers In Wilkinson \& Frazer, (Eds.), Gender Influences in Classroom Interaction. NY: Academic Press.

Büyüköztürk, Ş. (2016). Bilimsel Araştırma Yöntemleri (22.Baskı). Ankara: Pegem Akademi.

Campbell, J. (1996). A Comparison of Teacher Efficacy for Pre and In-service Teachers in Scotland and America. Education, 117 (1), 2-11.

Celep, C. (2002). The Correlation of The Factors: The Prospective Teachers' Sense of Efficacy and Beliefs, and Attitudes About Student Control. National Forum, 1-10.

Chacon, C. T. (2005). Teacher' Perceived Efficacy Among EFL Teachers in Middle Schools in Venezuela. Teaching and Teacher Education, 21(3), 257-272.

Collins, K. M. T. , James T. L., Minor L. C., Onwuegbuzie A. J., Witcher L. A. \& Witcher A. E. (2002). Relationship Between Teacher Efficacy and Beliefs About Education Among Preservice Teachers, Paper Presented at the Annual meeting of the Mid-South Educational Research Association, Chattanooga, TN, November 6.

Coskun, M. K. (2010). Din Kültürü ve Ahlak Bilgisi Ögretmenlerinin Özyeterlik Algılarının Çeşitli Değişkenler Açısından incelenmesi. Sosyal Bilimler Araştırmaları Dergisi, 1, 95-109

Çapa Aydın, Y., Uzuntiryaki Kondakçı, E., Temli, Y. ve Tarkın, A. (2013). Özyeterlik Kaynakları Ölçeği'nin Türkçe’ye Uyarlanması. İlköğretim Online, 12 (3), 749-758.

Çimen, S. (2007). Illköğretim öğretmenlerinin tükenmişlik yaşantıları ve yeterlik algıları (Yayınlanmamış Yüksek Lisans Tezi), Kocaeli Üniversitesi Sosyal Bilimler Enstitüsü, Kocaeli.

Daugherty, S. G. (2005). Teacher Efficacy and Its Relation to Teachers' Behaviors in the Classroom. (Unpublished $\mathrm{PhD}$ Thesis), University of Houston.

Eker, Cevat (2014). Sınıf Öğretmenlerinin Öz-Yeterlilik İnanç Düzeyleri Üzerine Bir Araştırma. Uşak Üniversitesi Sosyal Bilimler Dergisi, 7(1), 162-178.

Ekici, G. (2006). Meslek lisesi öğretmenlerinin öğretmen öz yeterlik inançları üzerine bir araştırma. Eurasian Journal of Educational Research, 24, 87-96. 
Gençtürk, A. (2008). İlköğretim Okulu Öğretmenlerinin Öz-Yeterlik Algıları ve İs Doyumlarının Çeşitli Değişkenler Açısından İncelenmesi (Yayımlanmamış yüksek lisans tezi). Bülent Ecevit Üniversitesi Sosyal bilimler enstitüsü, Zonguldak.

Gençtürk, A. ve Memiş, A. (2010). İlköğretim Okulu Öğretmenlerinin Öz-Yeterlik Algıları ve İş Doyumlarının Demografik Faktörler Açısından İncelenmesi. İlköğretim Online, 9 (3), 1037 1054.

Gibson, S. \& Dembo, M. H. (1984). Teacher efficacy: A construct validation. Journal of Educational Psychology, 76, 569-582.

Gür, G., Çakıroğlu, J. ve Çapa Aydın, Y. (2012). Sınıf, Fen ve Matematik Öğretmenlerinin Özyeterliklerini Yordayan Değişkenlerin İncelenmesi. Eğitim ve Bilim. 37 (166), 68-76.

Henson, R. K. (2001). Relationships between preservice teachers' self-efficacy, task analysis, and classroom management beliefs. Paper presented at the annual meeting of the Southwest Educational Research Association, New Orleans, LA.

Jones, M.G. ve Wheatley, J. (1990). Gender differences in teacher-student interactions in science classrooms. Journal of Research in Science Teach. 27 (9), 861-874.

Milli Eğitim Bakanlığ1 (2017). Öğretmen Yetiştirme ve Geliştirme Genel Müdürlüğü. Öğretmen Strateji Belgesi, 2017-2023. Erişim adresi: http://oygm.meb.gov.tr.

Milli Eğitim Bakanlığı (2017). Öğretmen Yetiştirme ve Geliştirme Genel Müdürlüğü. Öğretmenlik Mesleği Genel Yeterlikleri. Erişim adresi: http://oygm.meb.gov.tr.

Morgil, İ., Seçken, N. ve Yücel, A. S. (2004). Kimya Öğretmen Adaylarının Öz-Yeterlik İnançlarının Bazı Değişkenler Açısından İncelenmesi. Balıkesir Üniversitesi Fen Bilimleri Enstitüsü Dergisi, $6(1), 62-72$.

Pajares, M. F. (1992). Teachers' beliefs and educational research: cleaning up a messy construct. Review of Educational Research, 62(3), 307-332.

Sadker, M. ve Sadker, D. (1994). Failing at Fairness" NY: Simon \& Schuster.

Say, M. (2005). Fen Bilgisi Öğretmenlerinin Öz-Yeterlik İnanışları (Yayınlanmamış Yüksek Lisans Tezi). Marmara Üniversitesi Eğitim Bilimleri Enstitüsü, İstanbul.

Savran-Gencer, A. \& Çakıroğlu, J. (2007). Turkish pre-service science teachers' efficacy beliefs regarding science teaching and their beliefs about classroom management. Teaching and Teaching Education, 23, 664-675.

Şahin, E., (2010). İlköğretim Sınıf Öğretmenlerinin Öğretim Stili Tercihlerinin, Cinsiyetlerinin, Mesleki Kıdemlerinin, Özyeterlik Algılarının ve Özyönetimli Öğrenmeye Hazır Bulunuşluk Düzeylerinin Mesleki Yeterlikleri Üzerindeki Etkisi (Yayımlanmamış Doktora Tezi). Yıldız Teknik Üniversitesi, Sosyal Bilimler Enstitüsü, İstanbul.

Schunk, D. H. (1991). Self Efficacy and Academic Motivation. Educational Psychologist, 26, 207231. 
Skaalvik, E. M. \& Skaalvik, S. (2009). Teacher self-efficacy and teacher burnout: A study of relations Teaching and Teacher Education, 1-11.

Tschannen-Moran, M., Woolfolk Hoy, A. \& Hoy, W. K. (1998). Teacher efficacy: Its meaning and measure. Review of Educational Research, 68, 202-248.

Tschannen-Moran, M. \& Woolfolk Hoy, A. (2002). The Influence of Resources and Support on Teachers' Efficacy Beliefs. Paper Presented At The Annual Meeting of The American Educational Research Association, New Orleans. Erişim adresi: http://wmpeople.wm.edu/asset/index/mxtsch/mtmc. Erişim tarihi: 29/07/2018.

Tunacan, S. (2005). Beykoz İlçesindeki Lise Öğretmenlerinin İş Doyumunu Etkileyen Faktörler (Yayınlanmamış Yüksek Lisans Tezi). Yeditepe Üniversitesi, İstanbul.

Türk, Ö. (2008). İlköğretim sınıf ögretmenlerinin öz yeterlikleri ve meslek doyumlarının incelenmesi (Yayımlanmamış yüksek lisans tezi). Yeditepe Üniversitesi, Sosyal Bilimler Enstitüsü, İstanbul.

Umaz, D. (2010). Diyarbakır'daki ilköğretim öğretmenlerinin öz yeterlik düzeyi ve yaşadıkları iletişim sorunları (Yayımlanmamış yüksek lisans tezi), Yeditepe Üniversitesi Sosyal Bilimler Enstitüsü, İstanbul.

Üstüner, M., Demirtaş, H., Cömert, M.\& Özer, N. (2009). Ortaöğretim öğretmenlerinin öz yeterlik algıları. Mehmet Akif Ersoy Üniversitesi Ĕ̈itim Fakültesi Dergisi, 9 (17), 1-16.

Wheatley, K.F. (2002). The Potential Benefits of Teacher Efficacy Doubts for Educational Reform. Teaching and Teacher Education, 18, 5-22.

Woolfolk Hoy, A. \& Burke-Spero, R. (2005). Changes in teacher efficacy during the early years of teaching: A comparison of four measures. Teacher and Teacher Education, 21, 343-356.

Wertheim, C. \& Leyser, Y. (2002). Efficacy beliefs, background variables, and differentiated instruction of Israeli prospective teachers, The Journal of Educational Research, 11, 54-62.

Yılmaz, K. \& Çokluk-Bökeoğlu, Ö. (2008). İlköğretim okulu öğretmenlerinin yeterlik inançları. Ankara Üniversitesi Ĕgitim Bilimleri Fakültesi Dergisi, 41(2), 143-167.

Zararsız, N. (2012). Illkögrretim okullarında görev yapan öğretmenlerin öz yeterlik algllarının incelenmesi (Yayımlanmamış yüksek lisans tezi). Abant İzzet Baysal Üniversitesi Eğitim Bilimleri Enstitüsü, Bolu.

Zayimoğlu Öztürk, F., (2011). Sosyal bilgiler öğretmenlerinin ve ögretmen adaylarının ilköğretim sosyal bilgiler dersi ögretim programında yer alan ögrenme alanlarına ilişkin öz yeterlik düzeylerinin incelenmesi. (Yayımlanmamış Doktora Tezi). Gazi Üniversitesi Eğitim Bilimleri Enstitüsü, Ankara. 


\section{Extended Abstract}

The teaching profession is not only a profession that uses knowledge of the field and is maintained within the theoretical boundaries. Teachers should have general pedagogical competencies such as pedagogical field competencies, communication and classroom management, as well as possessing specific values. There is no doubt that it is necessary to go through a process of high-quality education in order to acquire these multi-faceted qualifications required by the teaching profession. In addition to having the knowledge and skills required by the teaching profession, other factors that affect the quality of teachers are their beliefs that they can fulfil their duties and responsibilities. Bandura (1997) emphasizes the importance of belief in the individual's ability to succeed, as well as having the necessary skills. Self-efficacy belief has been described by Bandura (1986, p. 391) as "judgments about the capacities of people to fulfil the actions necessary to perform a performance and to organize those actions" (Akbaş and Çelikkaleli, 2006). It is also stated that this belief affects four basic psychological processes such as (a) cognitive processes, (b) motivational processes, (c) emotional processes and (d) selection processes that have an important place in human life (Bandura, 1997, p. 5). Zimmerman (1995) defines the concept of self-efficacy as a personal judgment on the individual's ability to perform and accomplish a task.

Having information about the factors that affect teacher self-efficacy is important in order to strengthen teachers' competence judgments and contribute to their professional development. Based on the relationship between selfefficacy and achievement that Bandura put forward, it can be said that teachers with high self-efficacy will perform more effective teaching. Therefore, if factors affecting teacher self-efficacy are known, professional supports can be provided to improve the self-efficacy of teachers and the teaching process can become more effective. In this context, the aim of this research is to determine the self-efficacy levels of the classroom teachers who work in secondary schools from state schools affiliated to the Ministry of National Education. In the research, the following questions have been answered.

1. What are the self-efficacy levels of branch teachers?

2. Are the self-efficacy levels of branch teachers significantly different according to variables such as gender, branch, seniority, level of education, duration of school, number of teachers, place of work and number of students in school?

3. Is there a significant relationship between the self-efficacy levels of branch teachers, among the subdimensions of self-efficacy towards classroom management, self-efficacy towards student participation, and selfefficacy towards teaching strategies?

This research is in the instant scanning model. The universe of the research constitutes a total of 1602 teachers working in middle schools in the center of Elazı̆ and the districts in the academic year of 2017-2018. The sample forms a total of 360 teachers determined by simple random sampling. "Teachers' Sense of Efficacy Scale" developed by Tschannen-Moran and Hoy (2001) and adapted to Turkish by Çapa, Çakıroğlu and Sarıkaya (2005) was used as data collection tool in the research. Independent groups t-test was performed to determine whether there was a meaningful difference between the opinions expressed in terms of gender, education level, and studied settlement variables. In addition, one-way ANOVA was used to determine whether there was a 
meaningful difference between the views in terms of variables such as seniority, duration of school, number of teachers in the school and number of students in the school. In the cases where group variances were equal, LSD test, which is used for multiple comparisons of mean scores, has been tested whether there is a difference between the averages of the groups. Professional self-efficacy levels of the branch teachers participating in the research are sufficient in all sub-dimensions and in the whole scale. However, the level of self-efficacy of branch teachers towards student participation is lower than other sub-dimensions, such as increasing desire for students to work, supporting students' critical thinking skills, to motivate students who show little interest in lessons, to convince them to be successful in their lessons, to respond well to difficult questions of the students, to organize regular activities of class activities, to prepare questions to enable students to evaluate the students in the best way, to ensure that students obey class rules and to be able to cope with students who behave negligently. According to the gender variable, in the sub-dimensions of self-efficacy for classroom management and selfefficacy for teaching strategies and in the whole scale, self-efficacy levels of male teachers are higher than female teachers. According to the education level variable, there was no significant difference between the selfefficacy levels of the branch teachers. It was determined that self-efficacy levels of teachers who work in schools with a small number of students are lower than those who work in schools with a high number of students. There was no significant difference between the self-efficacy levels of the branch teachers according to their place of work, seniority and branch variables. 